AGRARIS: Journal of Agribusiness and Rural Development Research

Vol. 6 No. 1 January-June 2020

Article History:

Submitted: August 5th 2019

Accepted : March 30th, 2020
Nurliza $^{1 *}$, Agus Ruliyansyah $^{2}$, Rini Hazriani ${ }^{3}$

${ }^{1}$ Agribusiness Dept., Faculty of Agriculture, University of Tanjungpura

${ }^{2}$ Agrotechnology Dept., Faculty of Agriculture, University of

Tanjungpura

${ }^{3}$ Soil Dept., Faculty of Agriculture, University of Tanjungpura

*)Correspondence email: nurliza.spmm@gmail.com

\title{
Performance Behavior of Corn Smallholders for Sustainable Cooperative Change in West Kalimantan
}

\author{
DOI: https://doi.org/10.18196/agr.6186
}

ABSTRACT

The production of corn as the second most important cereal crops after rice is dominated by smallholders, particularly in West Kalimantan. However, smallholders in farmer cooperatives are unsustainable because of the lack of decision-making power at the grassroots level; limited access to land, capital, technologies, information and financial services; low market competitiveness; weak management; and limited policy and socio-cultural norms. This research aims to construct the behavior model for performance change of cooperative farmers in Rasau Jaya, Kubu Raya district, West Kalimantan. It involved 75 smallholders recruited using purposive sampling technique. In-depth interviews using the structural equation modeling/SEM based on the new institutional approach and the theory of planned behavior were used in the study. The findings proved that intentions and past behaviors have positive and negative influence on farmers' cooperative behavior, but contradicted with control. Therefore, there are several efforts for changing the behavior in corn farmers'cooperatives, i.e. the perceived behavioral control can stimulate the motivation to be long-lived performing based on the resources and opportunities; pro-environmental behavior needs to engage a supportive injunctive norm and a supportive descriptive norm; a subjective norm for motivation to exhibitthe positive experiential attitude; and the confidence to perform and control their performance.

Keywords: corn smalholders, behavior change, cooperative, theory of planned behavior, new institutional approach

\section{INTRODUCTION}

Gross Domestic Product (GDP) from the agricultural sector in Indonesia increased to $73.3 \%$ in the first quarter of 2019 from 46173.20 IDR billion in the fourth quarter of 2018, reaching an average of 68735.56 IDR billion from 2010 until 2019 (Trading-Economics, 2019). Therefore, certain agricultural products with high self sufficiency received special attention in the blueprint of the ASEAN Economic Community (AEC). In particular, this applies to corn which by far is among the four strategic commodities. 
Corn is also the second most important cereal crops after rice with significant growth of production over the last three decades. Thus, the government will continue to strengthen its competitiveness to take advantage of export opportunities to the border countries, particularly in West Kalimantan i.e. Aruk-Biawak (Sambas), Entikong-Tebedu (Sanggau) and Nanga Badau Lubuk Antu (Kapuas Hulu) (Agriculture-Ministry, 2017).

While, Kubu Raya district is one of the centers of corn commodity development in West Kalimantan through the Integrated Agribusiness Business Zone (KUAT), the sustainability of the Production Center Development Program to accelerate the development of agribusiness-oriented agriculture into a fast-growing region. Thus, Kubu Raya Government prepared 14 hectares of land in sub-district of Rasau Jaya as part of Intergreted Farming for Hybrid Corn Planting due to the market demand for sweet corn reaches 100 tons per month This is also in line with Minister of Agriculture Decree No. 472 in 2018 that every program and activity must be landed in an agricultural area with food priority commodities.

Moreover, there are some urgent matters related to farmers' cooperatives in supporting the sustainable development of corn. First, an increasing challenges of corn demand, such as the natural resource depletion and climate change, which require collaboration between farmers, extension, researchers, policy makers, private sectors, and many other development agencies. Therefore, the empowerment of smallholder farmers are expected to be able to facilitate smallholder mechanisms to improve the economic and social situation of farmers' households and communities, such as price and production, dissemination and adoption, and other indicators of member performance (DIIS, 2004; Alho, 2015). Second, the production modes of corn are dominated by smallholders, which then pushes the Indonesian Agriculture Minister to empower and synergize the farmer cooperatives with business activities in education for the food sovereignty (Andoko et al., 2018). Third, farmers' performance behavior within the context of cooperative societies is related to achieving effective translation of cooperative farmers' mission.

However, farmer cooperatives, particularly small farming groups, are unsustainable and not fully accommodate the interests of farmers (Nuraini, Darwanto, Masyhuri, \& Jamhari, 2016) because of the lack of decision-making power at the grassroots level, limited access to land, capital, technologies, information and financial services, urbanization of the workforce, intense competition, weak management skill, limited supporting policy, and sociocultural norms particularly for women (DIIS, 2004; Chen, 2014; Ishemo \& Bushell, 2017; Lazarte, 2017; Jaka \& Shava, 2018).

Thus, the research aims to construct the behavior model of corn farmers to optimize and encourage the farmers' performance for cooperative change toward sustainable farming and safeguard the environment. The research is based on the new institutional approach combined with the theory of planned behavior (TPB). The new institutional approach framework for stakeholders is related to organizations in social science due to simplification of the workings of institutions that focus on regulatory issues and constraints in particular institutions (Lang, 2018). While, the theory of planned behavior (TPB) links one's beliefs and 
behavior in agriculture as a cohesive social institution that provides stability and meaning to social life.

In the theory of planned behavior (TPB), attitudes toward the behavior, subjective norms, control, perceived behavioral control; and intentions, together with perceptions of behavioral control can be used to predict the intentions to perform behaviors of different kinds, which account for considerable variance in actual behavior (Ajzen, 1991). Thus, the framework of the corn farmers' performance behavior model is expected to be able to promote and encourage changes in farmers' behavior in institutions, especially farmers' cooperatives as a liaison between agro-food supply chains of small-scale producers and sustainable institutions for gaining more added values.

\section{METHODOLOGY}

The research was conducted in sub-district Rasau Jaya, Kubu Raya district, which is the center of corn production between April and May 2019 and one of the Integrated Agribusiness Business Zone (KUAT), the sustainability of the Production Center Development Program to accelerate the development of agribusiness-oriented agriculture into a fast-growing region in West Kalimantan.

The number of respondents are 75 participants with $10 \%$ of a margin of error in a sample (Omair, 2014). The purposive sampling technique based on the criteria of corn farmers' who are members of farmer cooperatives in a New Urban Area (KPB)/Independent Integrated City (KTM) Rasau Jaya compiled by referring to the regulation of the Minister of Manpower and Transmigration Number: 9 of 2012 concerning Guidelines for Managing Transmigration Data and Information.

In-depth interviews are used not only to provide information but also produce an understanding of challenging field conditions (Guest et al., 2013; Alshenqeeti, 2014; Palinkas et al., 2015) as complement in further quantitative method with the structural equation modeling/SEM. The structural equation modeling/SEM was used as a model framework based as statistical techniques to construct and test the statistical of causal models of the new institutional approach and the theory of planned behavior (Tarka, 2018), which behavior of members in the institution is influenced by three kinds of considerations, i.e. control beliefs, intentions, and past behavior from TPB questionnaire construction (Ajzen, 1991). Control is structured by instrumental and experiential aspects; intentions is structured by attitude, perceived norm, perceived behavioral control; past behavior is structured by past experience; behavior is structured by relative advantage, compatibility, complexity, and observability, and trialability.

SEM is also a stronger hybrid technique in terms of confirmatory aspects of factor analysis, path analysis and regression or considered as having interaction modeling, nonlinearity, correlated independent variables (Narimawati \& Sarwono, 2017). 


\section{RESULT AND DISCUSSIONS}

The framework of the corn farmers' performance behavior model, especially farmers' cooperatives, as a liaison between agro-food supply chains of small-scale producers and sustainable institutions for gaining more added values, is determined by the farmers' characteristics. The participants were mostly 40 to 45 years old; their ethnic is java. They had been married for more than 20 until 25 years, they had 4 family members, their education background is 9 years, and most of them had 2-10 year farming experience.

TABLE 1. FARMERS' CHARACTERISTICS

\begin{tabular}{|c|c|}
\hline Charachteristics & Percentage (\%) \\
\hline \multicolumn{2}{|l|}{ Age (year): } \\
\hline$\leq 30$ & 6.56 \\
\hline$>30-35$ & 6.56 \\
\hline$>35-40$ & 13.11 \\
\hline$>40-45$ & 18.03 \\
\hline$>45$ & 6.56 \\
\hline \multicolumn{2}{|l|}{ Religions: } \\
\hline Islam & 100 \\
\hline \multicolumn{2}{|l|}{ Ethnics: } \\
\hline Java & 95.08 \\
\hline Malay & 3.28 \\
\hline Dayak & 1.64 \\
\hline \multicolumn{2}{|c|}{ Family members (people): } \\
\hline$\leq 2$ & 8.20 \\
\hline 3 & 22.95 \\
\hline 4 & 42.62 \\
\hline 5 & 16.39 \\
\hline$>5$ & 9.84 \\
\hline \multicolumn{2}{|l|}{ Education (years): } \\
\hline$<6$ & 26.23 \\
\hline 6 & 26.23 \\
\hline$<9$ & 1.64 \\
\hline 9 & 29.51 \\
\hline$>12$ & 16.39 \\
\hline \multicolumn{2}{|c|}{ Farming experiences (years): } \\
\hline$\leq 0.5$ & 16.39 \\
\hline$>0.5-2$ & 11.48 \\
\hline$>2-10$ & 45.90 \\
\hline$>10-15$ & 9.84 \\
\hline$>15-20$ & 14.75 \\
\hline$>20$ & 1.64 \\
\hline
\end{tabular}

Source: author's analysis (2019)

As table 1 indicates, aging may affect different dimensions of $(\mathrm{Ng}, 2008)$, which may add value to their institution over their competition and encouraging long-term participation in social groups to help adapt to various activities (Lindsay-Smith et al., 2018). The older 
workers also represents a committed and diverse set of workers, which become a source of institutional knowledge, wisdom, and life experience (Vasconcelos, 2018). While, the effects of ethnic culture on cooperative and competitive behavior are confirmed by the collectivist culture of Java, which shows more cooperative behavior to adapt to changes (Cox et al., 1991; Dionne, 2015) and reflect social identity for facilitating cooperative assortment in complex societies (Smaldino, 2019).

Moreover, joining agricultural cooperatives has a positive impact on the wellbeing of smallholders, particularly for a bigger number of families due to their heterogeneous impact on wellbeing (Ahmed \& Mesfin, 2017). There is also significant relationship between education levels and farming experiences with attitudes towards organizational changes and their cognitive dimension for improving cooperative role in today's competitive world (Ravangard et al., 2014). Then, the behavior model of corn farmers was analyzed using SEM and tested for its validity and reliability, as presented in Table 2.

TABEL 2. VALLDITY AND RELIABILITY TEST

\begin{tabular}{|c|c|c|c|c|c|c|}
\hline \multirow{2}{*}{ No. } & \multirow{2}{*}{ Criterias } & \multirow{2}{*}{ Standard Values } & \multicolumn{2}{|l|}{ Initial } & \multicolumn{2}{|c|}{ Final } \\
\hline & & & Estimate Values & Conclusion & Estimate Values & Conclusion \\
\hline 1 & Chi Square $/ x^{2}$ & Small value & $158.89 \quad(P=0.00001)$ & Poorly & $\begin{array}{l}82.44 \\
(P=0.00004)\end{array}$ & Poorly \\
\hline 2 & $\chi^{2} / D F$ & $1,0 \geq x \leq 5,0$ & 2.34 & Good & 2.36 & Good \\
\hline 3 & NCP & $\begin{array}{l}\text { Small value with narrow } \\
\text { interval }\end{array}$ & $\begin{array}{l}15.89 \\
(0.0 ; 28.59)\end{array}$ & Good & $\begin{array}{l}12.46 \\
(0.0 ; 29.18)\end{array}$ & Good \\
\hline 4 & SNCP (NCP/n) & Small value & 0.43 & Good & 0.33 & Good \\
\hline 5 & RMSEA & $\leq 0,08$ & 0.112 & Poorly & 0.076 & Good \\
\hline 6 & $\mathrm{ECVI}$ & $\begin{array}{l}\text { Small value and close to } \\
\text { saturated ECVI }\end{array}$ & $\begin{array}{l}M=6.02 \\
S=4.92 \\
I=11.11\end{array}$ & Poorly & $\begin{array}{l}M=3.61 \\
S=2.97 \\
I=7.76\end{array}$ & Poorly \\
\hline 7 & AIC & $\begin{array}{l}\text { Small value and close to } \\
\text { saturated AIC }\end{array}$ & $\begin{array}{l}M=152.89 \\
S=182.00 \\
I=410.93\end{array}$ & Good & $\begin{array}{l}M=106.44 \\
S=110.00 \\
I=287.05\end{array}$ & Good \\
\hline 8 & CAIC & $\begin{array}{l}\text { Small value and close to } \\
\text { saturated CAIC }\end{array}$ & $\begin{array}{l}M=413.55 \\
S=422.02 \\
I=445.22\end{array}$ & Good & $\begin{array}{l}M=214.19 \\
S=255.07 \\
I=313.43\end{array}$ & Good \\
\hline 9 & $\mathrm{NFI}$ & $\geq 0,90$ & 0.62 & Poorly & 0.80 & Poorly \\
\hline 10 & NNFI & $\geq 0,90$ & 0.66 & Poorly & 0.79 & Poorly \\
\hline 11 & PNFI & Higher value & 0.82 & Poorly & 0.59 & Poorly \\
\hline 12 & $\mathrm{CFI}$ & $\geq 0,90$ & 0.65 & Poorly & 0.90 & Good \\
\hline 13 & $\mathrm{IFI}$ & $\geq 0,90$ & 0.58 & Poorly & 0.90 & Good \\
\hline 14 & RFI & $\geq 0,90$ & 0.63 & Poorly & 0.86 & Poorly \\
\hline 15 & GFI & $\geq 0,90$ & 0.84 & Poorly & 0.91 & Good \\
\hline 16 & AGFI & $\geq 0,90$ & 0.72 & Poorly & 0.84 & Poorly \\
\hline 17 & PGFI & $0-1$ & 0.66 & Good & 0.46 & Good \\
\hline 18 & RMR & $\leq 0,05$ & 0.076 & Poorly & 0.042 & Good \\
\hline 19 & $\mathrm{CN}$ & $\geq 200$ & 89.64 & Poorly & 178.52 & Poorly \\
\hline
\end{tabular}

Source: author's analysis (2019)

In the goodness of fit test of the re-specification model, there were eleven criteria in the GOF test which had good fit. Cooperative behavior as the unobserved variable/construct 
latent can be estimated through the observed variable or indicators of control, intentions, and past behavior which are 79 percent as considerable variance of actual behavior (Figure 1).

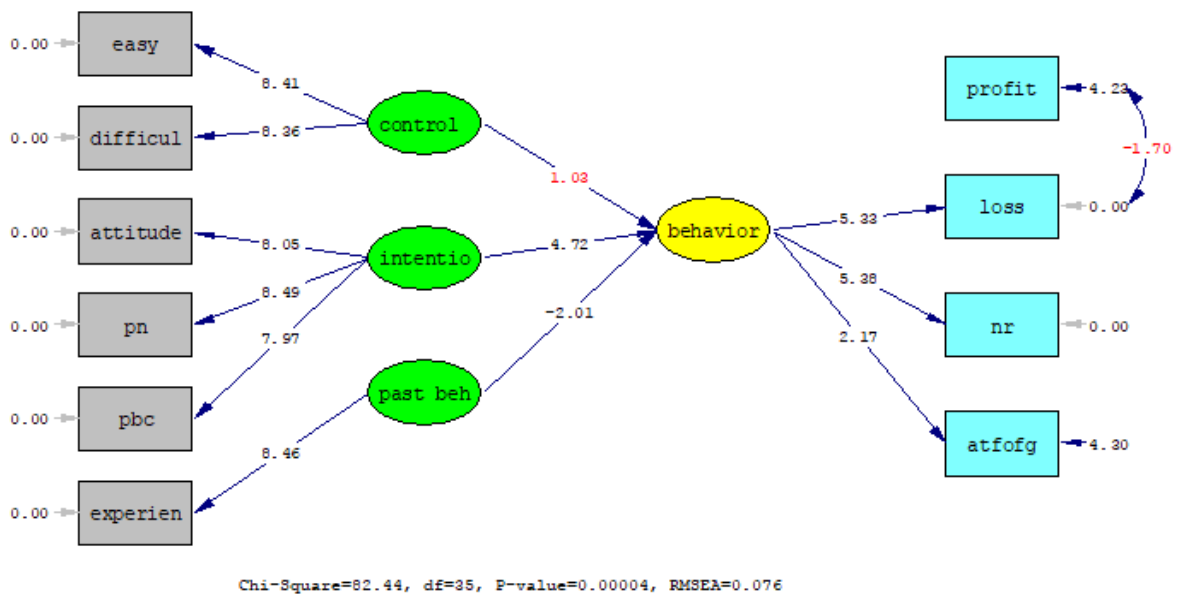

(a) t-value

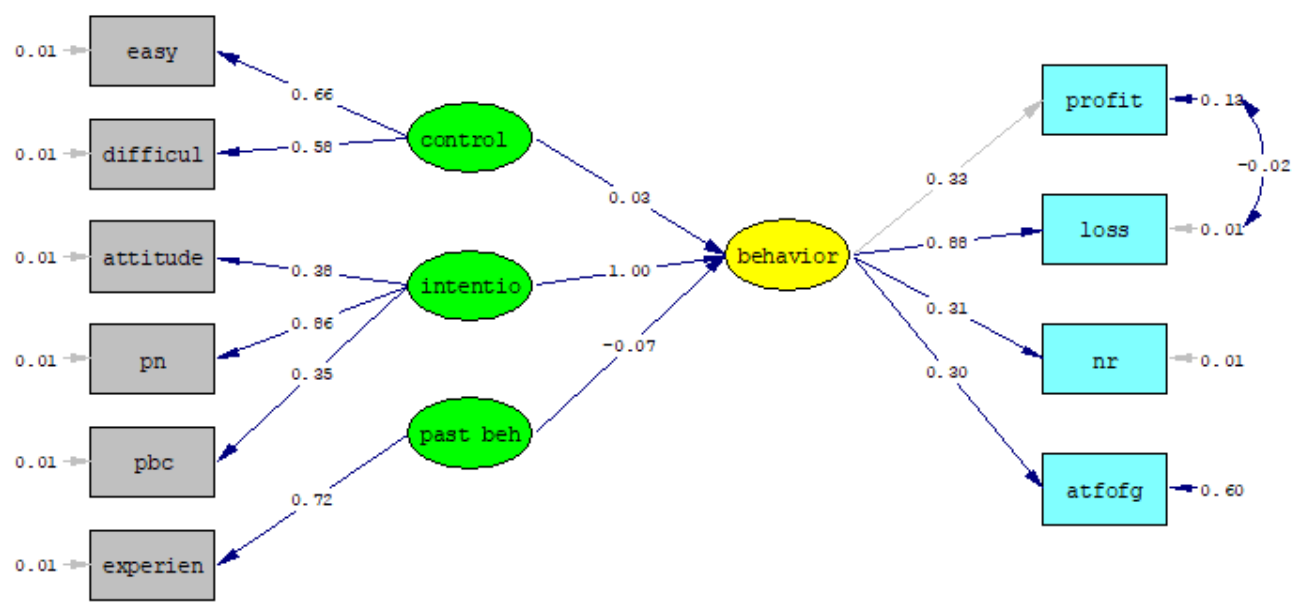

Chi-Square $=02.44, d f=35, P-v a l u e=0.00004$, RMSEA $=0.076$

(b) Coeficient estimate

FIGURE 1. (A) T-VALUE AND (B) COEFICIENT ESTIMATE OF PERFORMANCE BEHAVIOR MODEL

The structural model in Figure 1 shows that intentions and past behaviors have positive and negative influence on farmers' cooperative behavior, which are contradictory to the control. This shows that intentions will encourage farmers to actively engage in cooperatives, conversely with the behavior of the past that is felt to be useless. The positive influence of intentions on farmers 'cooperative behavior is due to the leaders' attitude, environmental factors, and non-economic drivers, such as socio-psychological aspect which influences the farmers' willingness to participate in cooperation (May, 2012; Wang et al., 2019).

However, inefficiency occurred because of an increase in heterogeneity of attitudes and objectives, particularly in terms of commitment and participation from their members (Grashuis \& Su, 2019). Therefore, an attitude as instrumental and experience together with 
a subjective norm can be motivation for the positive experiential attitude as its' influence to the intention (Wan et al., 2017).

On the other hand, the negative past behaviors shape their attitudes to farmers' cooperative behavior due to members' perceptions, beliefs and knowledge of agency problems, in terms of the decision problem and the follow-up problem (Bhuyan, 2007; Hakelius \& Hansson, 2016).

Control has no influence on farmers' cooperative behavior because of their lack capability in providing certain services; government officials and policy makers also poorly encourage the cooperative to improve their service quality (Chen et al., 2018). It also implied that the cooperatives' degree of success is weak due to the limited commitment of members towards cooperatives, also the members' trust towards farm operations profitability, age and experience of their leaders.

Meanwhile, the measurement model indicates that that most intentions have been influenced by perceived norms as an injunctive and descriptive aspect, followed by attitude as an instrumental and experience aspects, and perceived behavioral control as capacity and autonomy aspects. Therefore, we need to consider the relationship between injunctive and descriptive norms to understand their influence on behavioral intention. A conflict between the injunctive and descriptive aspects is usually associated with weak intentions to engage in pro-environmental behavior (Smith et al., 2012).

Furthermore, perceived behavioral control as capacity and autonomy aspect also affects intention because it can stimulate the motivation to be long-lived performing for the foundation of behavior formation and change (Yzer, 2012). This motivation is based on the resources and opportunities which are possible if they have confidence to perform and control their performance.

Then, the negative past behavior is mostly influenced by experience and direct knowledge due to scanning bias, dissonance distortion, heuristics in self-perception and use of behavior from others' reactions (Albarracín \& Wyer, 2000). Besides, individuals can rely on cues, other than directing experience to develop perceptions about injective norms.

Thus, understanding the cognitive reasoning process that drives decisions is the key to understanding farmers' behavior and the best approach to change behavior (Rose et al., 2018). Farmers can make decisions in different ways and each farmer's decision is influenced by unique social, psychological and contextual factors (Mankad, 2016).

\section{CONCLUSIONS}

The findings proved that intentions will encourage farmers to actively engage in cooperatives, conversely with the behavior of the past that is felt to be useless. Perceived norm as an injunctive and descriptive aspect are mostly influenced the intentions, followed by instrumental and experience aspects (attitude), and capacity and autonomy aspects (perceived behavioral control), which happend due to the leaders' attitude, environmental factors, and non-economic drivers, such as socio-psychological, influence farmers' willingness to 
participate in cooperation. Meanwhile, past experience caused the inactivity of farmers in cooperatives due to scanning bias, dissonance distortion, heuristics in self-perception and use of behavior members' perceptions, beliefs and knowledge. However, the control did not influence farmers' cooperative behavior due to the lack of capability of providing certain services; poorly government officials and policy makers for encouraging their service quality improvement in cooperatives. Therefore, there are several efforts for changing the behavior of cooperative corn farmers, as follows: the perceived behavioral control based on the resources and opportunities that stimulate the motivation to be long-lived performing; proenvironmental behavior needs to engage a supportive injunctive norm and a supportive descriptive norm; a subjective norm for motivation to exhibit positive experiential attitude; and the confidence to perform and control their performance.

\section{ACKNOWLEDGEMENTS}

We would like to express our sincere gratitude to the Directorate of Research and Community Service, Directorate General for Strengthening Research and Development of the Ministry of Research, Technology and Higher Education (RISTEKDIKTI) for funding this research through services to communities in community partnership program in 2019.

\section{REFERENCES}

Agriculture-Ministry. (2017). Corn Industry Development in Indonesia. Presented at the Meetings for the Development of Agricultural Cooperation, Ministry of Agriculture and Agro-Based Industry Malaysia, Kuala Lumpur, 5 July 2017 (hal. 1-60). Kuala Lumpur: MINISTRY OF AGRICULTURE REPUBLIC OF INDONESIA. Retrived July 27, 2019, from http://www.doa.gov.my/index/resources/aktiviti_sumber/sumber_awam/penerbita n/kertas_pembentangan/seminar_jagung_bijian_2017/kertas_pembentangan12.pdf

Ahmed, M. H., \& Mesfin, H. M. (2017). The impact of agricultural cooperatives membership on the wellbeing of smallholder farmers: empirical evidence from eastern Ethiopia. Agricultural and Food Economics, 5(6), 1-20.

Ajzen, I. (1991). The Theory of Planned Behavio. Organizational Behavior and Human Decision Processes, 50, 179-21.

Albarracín, D., \& Wyer, J. R. (2000). The Cognitive Impact of Past Behavior: Influences on Beliefs, Attitudes, and Future Behavioral Decisions. J Pers Soc Psychol., 79(1), 5-22.

Alho, E. (2015). Farmers' self-reported value of cooperative membership: evidence from heterogeneous business and organization structures. Agricultural and Food Economics, 3(23), 1-22.

Alshenqeeti, H. (2014). Interviewing as a data collection method: A critical review. English Linguistics Research, 3(1), 39-45.

Andoko, E., Candida, A., \& Zmudczynska, E. (2018). A Review of Indoneisa's Agriculture Development in Recent Years 2014-2018. Taipei. Retrieved July 27, 2019, from 
http://ap.fftc.agnet.org/ap_db.php?id=949: FFTC Agricultural Policy Platform (FFTC-AP).

Bhuyan, S. (2007). The "People" Factor in Cooperatives: An Analysis of Members' Attitudes and Behavior. Canadian Journal of Agricultural Economics/Revue canadienne d agroeconomie, 55(3), 275-298.

Chen, A. \&. (2014). ontributions and challenges of farmers' cooperatives to rural development in China. . Journal of Agriculture, Food Systems, and Community Development, 4, 1-21. Retrived July 28, 2019, from http://dx.doi.org/10.5304/jafscd.2014.044.005.

Chen, J., Chen, Q., Trienekens, J., \& Wang, H.-T. (2018). Determinants of cooperative pig farmers' safe production behaviour in China - Evidences from perspective of cooperatives' services. Journal of Integrative Agriculture, 17(10) , 2345-2355.

Cox, T. A., Lobel, S. A., \& McLeod, P. L. (1991). Effects of Ethnic Group Cultural Differences on Cooperatives and Competitive Behavior on A Group Task. Academy O/ Management Journal, 34(4), 827-847.

DIIS. (2004). Farmer Empowerment: Experiences, lessons learned and ways forward. Copenhagen. Retrieved July 28, 2019, from http://pure.diis.dk/ws/files/619348/Farmer_Empowerment_Volume_One.pdf: Danish Institute for International Studies (DIIS).

Dionne, K. Y. (2015). Social networks, ethnic diversity, and cooperative behavior in rural Malawi. Journal of Theoretical Politics, 27(4).

Grashuis, J., \& Su, Y. (2019). A REVIEW OF THE EMPIRICAL LITERATURE ONFARMER COOPERATIVES: PERFORMANCE, OWNERSHIPAND GOVERNANCE, FINANCE, AND MEMBER ATTITUDE. Annals of Public and Cooperative Economics, 90(1), 77-102.

Guest, G., Namey, E. E., \& Mitchell, M. L. (2013). Collecting Qualitative Data: A Field Manual for Applied Research. Thousand Oaks, California: SAGE Publications Ltd.

Hakelius, K., \& Hansson, H. (2016). Members' attitudes towards cooperatives and their perception of agency problems. International Food and Agribusiness Management Review, 19(4), 23-36.

Ishemo, A., \& Bushell, B. (2017). Farming Cooperatives: Opportunities and Challenges for Women Farmers in Jamaica. Journal of International Women's Studies, 18(4), 13-29.

Jaka, H., \& Shava, E. (2018). Resilient rural women's livelihoods for poverty alleviation and economic empowerment in semi-arid regions of Zimbabwe. Jamba: Journal of Disaster Risk Studies, 10(1), 524-534.

Lang, T. (2018). Institutional Theory, New. Dalam E. b. Rojek, The Blackwell Encyclopedia of Sociology (hal. 1-3). United Kingdom: John Wiley \& Sons, Ltd. Retrieved July 29, 2019, from https://www.researchgate.net/publication/319204204_Institutional_Theory_New.

Lazarte, A. (2017). Understanding the drivers of rural vulnerability. Employment Working Paper No. 214. Geneva, Switzerland. Retrieved July 28, 2019, from 
https://www.ilo.org/employment/Whatwedo/Publications/workingpapers/WCMS_568736/lang-en/index.htm: International Labour Organization (ILO).

Lindsay-Smith, G., O’Sullivan, G., Eime, R., Harvey, J., \& van Uffelen, J. G. (2018). A mixed methods case study exploring the impact of membership of a multi-activity, multicentre community group on social wellbeing of older adults. BMC Geriatr., 18, 226-239.

Mankad, A. (2016). Psychological influences on biosecurity control and farmer decisionmaking. A review. Agronomy for Sustainable Development, 36(40), 1-14.

May, D. E. (2012). Non-Economic Drivers Influencing Farmers' Incentives to Cooperate:Do they Remain Robust through Policy Changes? Journal of Rural Cooperation, 40(2), 217-238.

Narimawati, U., \& Sarwono, J. (2017). Structural Equalion Modeling (SEM). Jakarta: Salemba Empat.

Nuraini, C., Darwanto, D. H., Masyhuri, M., \& Jamhari, J. (2016). Model Kelembagaan pada Agribisnis Padi Organik Kabupaten Tasikmalaya. Agraris, 2(1), 9-16.

Ng, T. W. (2008). he Relationship of Age to Ten Dimensions of Job Performance. Journal of Applied Psychology 93(2), 392-423.

Palinkas, L. A., Horwitz, S. M., Green, C. A., Wisdom, J. P., Duan, N., \& Hoagwood, K. (2015). Purposeful sampling for qualitative data collection and analysis in mixed method implementation research. Adm Policy Ment Health, 42(5), 533-544.

Ravangard, R., Sajjadnia, Z., Jafari, A., Shahsavan, N., Bahmaie, J., \& Bahadori, M. (2014). The association between work ethics and attitudes towards organizational changes among the administrative, financial and support employees of general teaching hospitals. J Med Ethics Hist Med., 7, 12.

Rose, D. C., Keating, C., \& Morris, C. (2018). Understand how to influence farmers' decisionmaking behavior: a social science literature review. Warwickshire: Agriculture and Horticulture Development Board (AHDB).

Smaldino, P. E. (2019). Social identity and cooperation in cultural evolution. Behavioural Processes, 161, 108-116.

Smith, J. R., Terry, D. J., Louis, W. R., \& Greenaway, K. (2012). Congruent or Conflicted? The Impact of Injunctive and Descriptive Norms on Environmental Intentions. Journal of Environmental Psychology, 32(4), 353-361 .

Tarka, P. (2018). An overview of structural equation modeling: its beginnings, historical development, usefulness and controversies in the social sciences. Qual Quant, 52(1), 313-354.

Trading-Economics. (2019). Indonesia GDP From Agriculture. New City, New Yorks. Retrieved July 27, 2019, from https://tradingeconomics.com/indonesia/gdp-fromagriculture: TRADING ECONOMICS.

Omair, A. (2014). Sample size estimation and sampling techniques for selecting a representative sample. Journal of Health Specialties, 142-147. 
Vasconcelos, A. (2018). Older workers as a source of wisdom capital: broadening perspectives. Revista de Gestão, 25(1), 102-118.

Wan, C., Choi, S., \& Shen, G. Q. (2017). Experiential and instrumental attitudes: Interaction effect of attitude and subjective norm on recycling intention. Journal of Environmental Psychology, 50, 69-79.

Wang, Y.-n., Jin, 1., \& Mao, H. (2019). Farmer Cooperatives' Intention to Adopt Agricultural Information Technology-Mediating Effects of Attitude. Information Systems Frontiers, 21(3), 565-580.

Yzer, M. C. (2012). Perceived Behavioral Control in Reasoned Action Theory: A Dual-Aspect Interpretation. ANNALS, AAPSS, 640, 101-117. 